Mediterranean Journal of Humanities mjh.akdeniz.edu.tr IV/2, 2014, 89-112

\title{
Some Reasons for the Currency Reform of A.H. 77/696-7 A.D.: The Figure on the Obverse, 'the Caliph, the Prophet, or an Image of an Idol of Solid Hammer-Beaten Metal?'
}

\author{
Hicri Takvim'e göre M.S 77/696-7'deki Para Birimi Reformuna İlişkin Bazı \\ Sebepler: Ön Yüzdeki Figür, 'Halife, Peygamber, veya Çekiçle Dövülmüş Katı \\ Bir Metal Üzerindeki Figürün Görüntüsü’
}

T. Mikail P. DUGGAN*

\begin{abstract}
This article suggests there were quite specific reasons for the change in A.H. 77/696-7 to a reformed dīnār, the change from a figural to an epigraphic Islamic currency even though this reformed currency carrying only script was itself bida. It is suggested that this reform was associated with the arrival in Damascus in 696-7 A.D. of the third envoy from Emperor Justinian II demanding the return of the Christian Trinitarian tiraz to the coinage and to other official items, with the associated threat that if this was not done an imprecation on the Prophet would be struck on the widely circulated East Roman currency. It is suggested the depiction of the 'Standing Caliph' struck on the obverse of 'Abd al-Malik's dīnārs from 74 to 77 A.H. was misunderstood by some Christians as carrying a depiction of the Prophet, or of an idol of the Almighty, an idol thought have been to be worshipped by Muslims, rather than being a depiction of the Caliph. To prevent any further confusion concerning the relationship between legend and image on the obverse of the dīnār, the image was dispensed with, resulting in the epigraphic type of dīnār.
\end{abstract}

Keywords: Currency reform, standing Caliph, ‘Abd al-Malik, image, icon, idol

Öz: Bu makale, Hicri Takvim’e göre 77 (696/7) y1lında reforme edilmiş dinara, yani şekilsel olandan epigrafik İslami para birimine geçmenin, her ne kadar reforme edilen bu para birimi sadece bida yazısı taşıyor olsa da, oldukça özel sebepleri olduğunu önermektedir. Bu reformun, imparator II. Iustinianus'un Hıristiyan teslis prensibine ait olan "tirazın" sikkelere ve diğer resmi eşyalara geri dönmesini talep eden ve bu yapılmadığı takdirde peygambere yapılacak bir lanetlemenin oldukça geniş bir alanda dolaşımda olan Doğu Roma parasına basılmasıyla tehditte bulunan üçüncü elçisinin M.S 696-7 de Şam'a varışıyla ilişkili olduğu önerilmektedir. Hicri takvime göre 74 ve 77 yılları arasında Abdal Malik'in dinarlarının ön yüzünde basılan "Ayakta Duran Halife" betimlemesinin bazı Hıristiyanlar tarafindan Peygamberin ya da "her şeye gücü yeten (Allah'ın)" Müslümanlar tarafindan tapınılan bir putun betimi olduğu şeklinde yanlış anlaşıldığı ve yorumlandığı önerilmektedir.

Anahtar sözcükler: Para birimi reformu, ayakta duran Halife, ‘Abd al-Malik’, görüntü, ikon, figür

The depiction of a standing figure with a sword in a scabbard was struck on the obverse of gold dīnārs, of which 8 examples are known today (In addition there are both modern copies and fakes of these dīnārs. This is the dīnār type termed by Treadwell 2009, 362, the "Caliphal Image

* Lecturer, Art Historian, Akdeniz University, Mediterranean Civilisations Research Institute, Antalya, tmpduggan@yahoo.com 
Phase”, extending from 74-77 A.H.), probably minted in Damascus (Miles, 1967, 205), and examples of which are today in the collection of the National Museum of Pakistan, Karachi, dated 74 A.H./ 693-4, in the American Numismatic Society, Metropolitan Museum, New York, dated 75 A.H./694-5 A.D. (American Numismatic Society ANS 1970.63.1, weight 4.461 g., dia. 20 mm., dated h. 75, 694-5), and of 76 A.H./695-6 A.H. in the British Museum, all carrying the same legend on the obverse margin around this figure, as does that struck in 77 A.H./696-7 A.D. in the Ashmolean Museum, Oxford (Figs. 1-3) (CM 1954 10-11 2. The legend on the reverse margin reads: bism Allāh ḍuriba hadhā al-dīnār fì sanat sitta wa sab īn (In the name of God, this dīnār was struck in the year 76" 695-6 A.D.). Concerning the image on the reverse, see, Miles, 1952; "The lance and the 'globe or capital on a column on a stepped platform' should be seen as a non-venerated object of pride, power and victory and as a substitute for the symbols of the other religions, but they do not stand for Islam as a religion" Heidemann, 2010, 34. It seems possible that this column was regarded as a marker, a mânar, a sign of difference, like the painted column that marked the division between Caliphal and East Roman territory in northern Syria, Eutychius, a Melkite priest of Alexandria (d. 940) records that in the 630's, during a truce in the conquest of Syria, with the consent of Abu 'Ubaydah ibn Jarrah (d.638-9), a column was erected at Qinnasrin, marking the border in Northern Syria between East Roman territory and that of the Caliphate, see Graber, 18, 1964, 69), and a further surviving copy struck in 77 A.H. in the Oriental Coin Cabinet, Jena (Inv. No. 303-A02). The legend on the obverse margin around this figure reads: bism Allāh lā-ilaha il-Allāh wa / ḥdahu Muhammad rasūl Allāh -"In the name of God. There is no god but God alone. Muhammad is the messenger of God." These dīnārs were struck in each lunar year during the period between 74 and 77 A.H. (693-4 and 696-7 A.D.) during the reign of the Marwanid Omayyad Caliph Abu'l-Walid 'Abd al-Malik b. Marwān I (65-86 A.H./685-705 A.D.) (Miles, 1967, 212-4). This type replaced the earlier dīnār-type of 'Abd al-Malik carrying no inscription around the copy of the nomismata depiction of the 'three

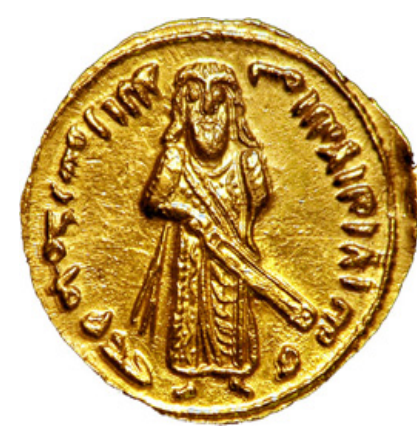

Fig. 1. Dinar from the Metropolitan Museum, New York, met mus.org Dated A.H. 75, 694-5 A.D. emperors' that was briefly struck after 72/691-2 (Heidemann, 2010, 29).

This same standing figure also occurs in formerly Persian territory on dirhams that carry on the other face the depiction of a typical Sassanid ruler (See for example, Graber, 1987, Fig. 18), and it seems probable this image was first struck on the dirhams minted by Al-Hajjaj ibn Yusuf al-Thaqafi in formerly Persian territory (ibn Khaldun writes, 'According to reports, 'Abd al-Malik ordered al-Hajjaj to coin dirhams, and bad coins (began to) be distinguished from good ones.', Khaldun, 2005, 217, which may indicate changes to the coinage happened under al-Hajjaj in Iraq before they occurred in the west in formerly East Roman territory, with issues of the standing figure on the dirhams preceded those on the dīnārs) and then quickly also came into use in formerly East Roman territory, with the issuing of silver dirhams late in 72 A.H. preceding the issuing of dīnārs of this type in 74 A.H. (Treadwell, 2005, 1-28).

This depiction of a standing figure with a sword in a scabbard, with minor variants such as in the type of design on the garment and in the hair style, was also struck on copper fulus emissions from a variety of mints including: Iliya-Jerusalem, Aylah (Probably struck at Iliya on behalf of the port of Aylah), Ludd, Amman, Damascus, Harran, al-Ruha-Urfa-Sanliurfa, Ma'arrat Misrin, Baalbek, Manbij, Sarmin, Qinnasrin, Hims (Emesa-Homs), Halab (Aleppo), Jibrin, Qurus and Tanukh. 
It seems most probable that the initial employment of this image on dirhams, probably struck first in Iraq and then in Syria, was probably directly related to the ending of the six and a half month siege of Makkah in 72 A.H./October 692 by the Caliph 'Abd al-Malik's general AlHajjaj ibn Yusuf, when the longstanding rival claimant to the Caliphate with strong support in al-Hijaz, Basra and elsewhere, 'Abdullah ibn az-Zubayr, the grandson of the first Caliph Abu Bakr (c. 573-August 23, 13 A.H./ 634) was finally defeated and beheaded, with his head sent to 'Abd al-Malik in Damascus, and, in consequence, the striking of this particular image on the dirhams minted at this time can be understood as being employed to signify the ending of the Second fitna - Civil War (680-92) and officially marking the reuniting of the Caliphate under the Caliph 'Abd al-Malik - at the haj in 688 there had been the banners of four parties: Ibn alZubayr, the Kharijites, the Shi'ites and the Umayyads (Peters, 1994, 65) - with the prominent sword, a perhaps necessary reminder of the temporal consequences of any further opposition to the Marwānid 'Abd al-Malik's rule over an undivided Caliphate, the response being the dispatch of the extremely formidable Al-Hajjaj ibn Yusuf al-Thaqafi.

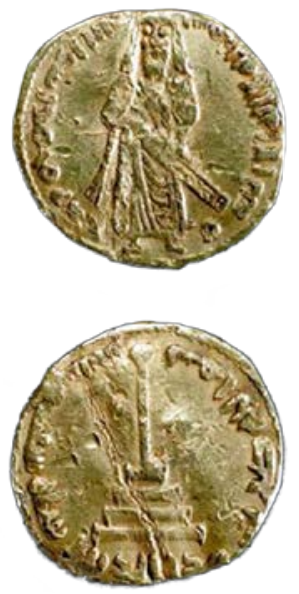

Fig. 2. British Museum CM 1954 10-11 2. Dated A.H. 76, 695-6 A.D.

These early Islamic depictions of a standing figure with a sword have been studied over the course of more than a century as they raise a number of questions, not least because following this figural issue, there was the near cessation by Muslim rulers of issues of figural coinage for more than 400 years following this coinage reform of 77 A.H./696-7 (See for example, Broome, 1985,13 ) until the mid- $12^{\text {th }}$ c. onwards, when there were numerous bronze Ayyubid and Artukid, and gold, silver and bronze Rum Seljuk figural issues (See for examples, Pancaroğlu, 2005, 398-9). This absence of figural images on Islamic gold coinage after 77 A.H., even though for example the seal of this Caliph, 'Abd al-Malik, carries affronted lions on one face and affronted birds on the other (Graber, 1987, Fig. 21, although if it predates the reform of the coinage or if this seal is later is uncertain.), and figural medallions of various types in both gold and silver were struck for limited circulation within Islamic territory during these centuries, suggests that the change to a largely non-figural coinage was not primarily due to any opposition or aversion to the use of figural imagery per se (Contra for example ibn Khaldun, "The non-Arabs used coins and engraved special pictures on them - for example, a picture of a ruler at the time of issue, a fortress, some animal or product, or something else. This remained the practice of the non-Arabs down to the end of their power. When Islam appeared, the practice was discontinued, because of the simplicity of Islam and the Bedouin attitude of the Arabs", Khaldun, 2005, 217, that ignores the existence of these figural issues; as also contra Colish, 1997, 124, "Finally, like John of Damascus, the Near Eastern patriarchs defended icons because they were living under Muslim rulers who regarded figural art as idolatry". However, rather than as stated in these examples, that Muslim rulers 'regarded figural art as idolatry', it was rather the case that at the time of John of Damascus and in this period that the depictions of plants, date palms, scrolling foliage, vases and fruit, depicted in mosaic work was in all probability employed on the walls in the restoration of the Ka'ba in 684, (Creswell, 1958, 15), like that inside the Dome of the Rock of 691, were completed, as also the later similar mosaic work in the Church, shared between the Christians and Muslims from 638 onwards, of the Nativity, Bethlehem, after 694; figurative work completed during the rule of the Caliph 'Abd alMalik who circulated this figural currency, while the pictorial mosaics on the walls of the Great 
Mosque in Medina were completed c. 705-12, and those remaining today on the walls of the Great Mosque in Damascus, capital of the Caliphate, including depictions of buildings, trees and

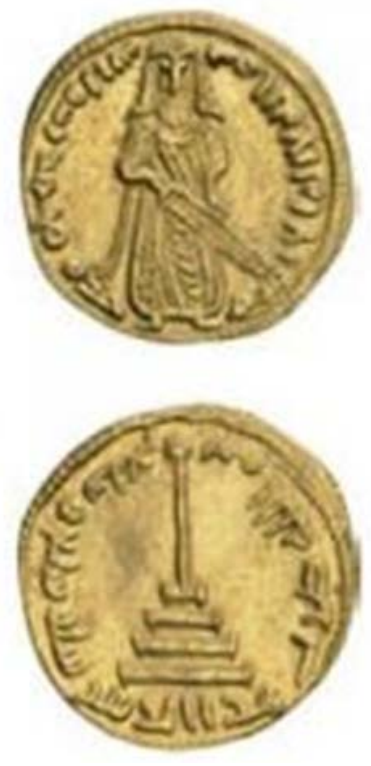

Fig. 3. Ashmolean Museum, probably Damascus, Dated A.H. 77, 696-7 A.D.

plants, boats etc., which were begun under the Caliph al-Walid I, with the mosque completed under the Caliph Suleyman I in 715; while the slightly later Omayyad "desert palaces" were replete with figural depictions, rulers, people, animals, plants and birds, which were painted, depicted in mosaic, carved in relief and carved in the round. It was rather the case that this was a period during which Muslim Caliphs and others employed a great deal of figural imagery over a great variety of surfaces, both public and private, as well as, under 'Abd al-Malik on the coins of these emissions carrying this image of a standing figure with a sword. Likewise B. Lewis regrettably writes on this matter of figural images on coins: 'At first, as we have seen, they were based on Persian or Byzantine models, and these often bear figural designs that are alien to Islamic ways of thought' (Lewis 1992, 54, paraphrasing ibn Haldun's $14^{\text {th }}$ c. remark concerning the late $7^{\text {th }} c$., "but engraved words on it, rather than pictures, because eloquent words were obviously more congenial to the Arabs. Moreover, the religious law forbids pictures" (Khaldun 2005, 217), while at the same time the illustrations, (Lewis 1992, Figs. 6, 7), of both the standing caliph coin and the horseman on that of al-Muqtadir (908-32) and also, (Lewis 1992, Fig. 40), the camel and guide on that minted by al-Mutawakkil (847-61), are figural images, not in

fact during this time in any way alien to Islamic ways of thought and which were struck by both Omayyad and Abbasid Caliphs during the course of 300 years. Further, in regard to images, M. Whittow writes, "the Islamic world where sacred figural images were prohibited" (Whittow 1996, 141), is quite incorrect, they were not prohibited and numerous examples of the depiction of sacred figural images are recorded and some number survive in manuscript illuminations, on metal-ware, carved in stone etc. including depictions of the Prophets, angels including the recording angels, Burak, some within the Ka'ba in Makkah that were personally protected by the Prophet himself from defacement in 630, etc.), as there were subsequent figural issues of commemorative medallions struck on behalf of Caliphs, Sultans and Viziers and which carried images/depictions/portraits on them (Figural issues of medallions include: those carrying the depiction of Ja'far b. Yahya b. Khalid al-Barmaki (d. 803), the Vizier to the Abbasid Caliph Harun b. al-Mahdi, Abu Ja'far al-Rashid (786-809), who had minted a large number of very large gold medallions, (Daftar, 1980, 191-2); those of the Abbasid Caliph Al Muttawakil, (Daftar, 1977, 170-1); those depicting the Abbasid Caliph Abu'l Fadl al-Muqtadir (908-32), the Caliph Abu'l Qasim al-Muti (946-74), and one reported as carrying depictions of the Caliph Radi (934-40) and the slave-soldier Bajkam, (Arnold, 1965, fig. LIX a and b, 125-126), citing Mas'udi; as also the gold commemorative medallion issued by Izz al-Dawlah and al-Tai of 9756 (Ettinghausen, \& Graber, 1994, Fig. 253); and that issued in h. 455, 1063 to mark the marriage of Sayyida, the daughter of Abbasid Caliph Abu Ja'far al-Qa'im (1031-75) to the first Great Seljuk Sultan, Rukn-ad-Dunya-wa-d-Din Tughrul I (1038-63), carrying figural depictions of the Caliph and the Sultan, (Artuk, 1960, Lev. III, 39-40; Batur, 1994, Cat. No. 3; Senturk, Özpalabiyiklar, 2004, INV. No. 8187, 249), as well as numerous figural emblems on seals (Khaldun, 2005, 201, 'He sealed them with the seal of the ruler, which was a signet upon which 
the name of the ruler or his emblem was engraved'), and a very great quantity of figural depictions over a very wide range of materials which were produced during this period from the late $7^{\text {th }}$ c. to the $12^{\text {th }}$ c., including portraits of Caliphs woven in textiles ("Around the large carpet were medallions in which there were figures of people and writing in Persian. I was skilled in the reading of Persian, and there, on the right of the prayer carpet was the image of a king with a crown on his head. I read the writing: 'This is the picture of Shiruya, the murderer of his father Abrawiz. He reigned six months'. Then I saw various portraits of kings and my eyes alighted on a picture on the left of the prayer carpet, on which was written: 'This is the portrait of Yazid ibn Walid ibn 'Abd al-Malik. He reigned six months' I was surprised at that, and at their happening to be on the right and left of al-Mustansir's throne (861-2) and I said: 'I do not think his power will last more than six months.' And, by Allah, so it was”. Related by Abu 'Abbas Muhammad ibn Sahl and cited by Mas'udi in his Murudj al-Dhahab of 943 and by Suyuti in his Ta'rikh alKhulafa, translated in, Serjeant, 1972, 9; quoted in, Fairchild-Ruggles, 2011, 57-59), with wall paintings and miniatures produced depicting rulers (See for example the later portraits of rulers in situ today painted on the wall of the Omayyad Qasr 'Amra, Jordan, of the enthroned Caliph Abu'l Abbas al-Walid I (705-15) or Walid II b. Yazid II, prior to 744, with attendants on either side of the throne, Graber, 1987, Fig. 3, and those which are recorded, although not surviving in miniatures, see for examples: Browne, 1997, I, 332; Barry, 2004, 66) and other human figures and works of figural sculpture in low and high relief and in the round, in metal, stone, stucco, pottery, ivory, sugar, glass, wood, etc. (For some examples of figural art from this period of 400 years, see the photographic illustrations in, Graber, 1987, Figs. 3, 3a, 79-89; Hattstein, \& Delius, 2000, illustrations on pages: 49, 60, 69, 80-87; Ettinghausen, \& Graber, 1994, Figs. 26, 28-43, 47; Duggan, 2012). It is noteworthy in this respect that the issuance of images on coins other than dīnārs continued in places if at a much reduced level after the reform of 77 A.H., as with the images on the Arab-Sasanian coppers of Iran. There is, of course not one single ayetverse in the Holy Koran that forbids the making of either images or sculptures, while sculptures are recorded as being made by the jinn for the Prophet Süleyman (Holy Koran, Sura Saba', 34: 13 "They (the jinn) made for him whatever he (the Prophet Süleyman) pleased: shrines and statues, basins as large as watering-troughs, and built-cauldrons"), but rather, that this change, the reform of the coinage was carried out for some other reason (Graber, 1987, 93, states there is no evidence for a Jewish influence in the h. 77 reform of the currency and there seem to be no contrary indications), and therefore neither the anti-figural largely Isra'iliyat hadith (Creswell, 1958, 98, who suggests that in part, this attitude was the influence of Jewish converts to Islam (Isra'iliyat) such as the Yemenite Jew Ka'b al-Ahbar, who converted to Islam in 638 and, "who is frequently cited as an authority for hadith", and the Jewish converts to Islam and early expositors of the Koran, 'Abd Allah ibn Abbas, Abu Huraira and Wahb ibn Munabbih, whom, it is suggested, brought into Islam the longstanding Jewish opposition to images and which came to the fore in the second half of the $8^{\text {th }}$ century under the Abbasid Caliphate and which has been a force in parts of Islamic society from that point onwards (also Arnold, 1965, 10-11; Brend, 1991, 19). Likewise concerning the later iconoclast edict, reported by Christian sources, to have been issued by the Caliph Yazid II (720-24), see: King, 1985, 267-77; Vasiliev, 1954, 85-150; that this Caliph, more absorbed in hunting, wine drinking, "absorbed in poetry and music, than in the Koran and state affairs", Hitti, 1991, 279, issued any such document seems itself to be strange, a document that fits more with the contemporary internal Christian polemics and actions of the Christian iconoclast party in greater Syria in the $8^{\text {th }} \mathrm{c}$. and the removal of icons from churches. As G. R. D. King, 1985, clearly explains, there was no antipathy in Islam at this time to the pictorial depictions of people, or to icons, there was rather an antipathy to the 
Christian Cross and to what it symbolized, as also to the doctrine of the Trinity and its representation, as contradicting the status of Jesus as a Prophet recorded in the Holy Koran, and through giving partners to the One God. Pictorial representation as such, as well as sculpture, as distinct from idols, was accepted by the Omayyads, with this exception of Caliph Yazid II's decree, perhaps the work of an image adverse adviser, apparently called Tessarakontapekhys (a Greek name apparently meaning 40 cubits-forearms), a Jew from Tiberius, said to have been the advisor to Caliph Yazid II, who was executed by order of the Caliph Walid II, Brooks, 1899, 26, fn. 2.

Subsequently, at the $7^{\text {th }}$ Oecumenical Synod of 787 at Nicaea (Iznik), "John, the representative of the Eastern Patriarchs, in explaining the origin of the iconoclastic heresy, attributed to a Jewish magician the intention "to destroy the images, not only in churches, but also those, of whatever kind they may be, that added beauty and adornment to city squares", Ainalov, 1961, 190, fn. 20; while, “Theophanes, writing about 813, argued that Leo's iconoclasm was influenced by Jewish ideas imported from an iconoclastic Islamic world", Barber, 2002, 8, fn. 6, likewise placing the responsibility for iconoclasm upon Jewish converts, quotes that clearly indicate that it was Jewish converts who, at least in part, instigated-instituted iconoclasm in both religions, a consequence of Orthodox Jewish iconoclasm, a response to pagan Jewish idolatry, as recorded in the Jewish Old Testament, in the 10 commandments given to the Prophet Moses, Exodus, Ch. 20, v. 4-5, "Thou shalt not make unto thee any graven image of anything that is in heaven above, or that is in the earth beneath, or that is in the water under the earth: Thou shalt not bow down thyself to them, or serve them", perhaps also, Ch. 20, v. 23, "Ye shall not make with me gods of silver, neither shall ye make unto you gods of gold"), nor any proposed opposition to images per se based upon these considerably later widely circulated relations, could have been the actual reason for this change from a figural coinage to a largely non-figural Islamic currency following the completion of the 77 A.H. currency reform.

Consequently the reasons for this change to the issue of a largely non-figural Islamic currency in 77 A.H., is clearly not directly related to the later so called 'iconoclastic' edict of the Caliph Yazid II (720-24) reported in Christian sources (Barber, 2002, 8; King, 1985, passim), nor to the later East Roman iconographic controversy, officially beginning 30-31 years after these figural dīnārs were last minted, with the promulgation of the edict against icons by Leo III in 725-6 (For suggested dates for the start of East Roman iconoclasm of 725-6 and 729-30 see, Barber, 2002, 9), and, in consequence of the above, the reasons for this important change made to the appearance of this Islamic coinage should be looked for elsewhere. O. Graber wrote concerning this change: "At a chronologically clear moment which corresponds to the time of the Dome of the Rock, the very official art of coinage replaced representational formulas with writing and this change was irreversible. It obviously was the result of a need or an attitude that can at least be dated, if not yet explained" (Graber, 1987, 91). For more recent views on this matter that argue the adoption of an aniconic coinage in 77 A.H. was a consequence of a process of standardisation of the currency, and that it was, "the insurmountable challenge of creating a new numismatic iconography out of both Sassanid and Byzantine Late Antique traditions which brought the previous metal figural currency of the transitional period to a close", Treadwell, 2009, 378-9; or, alternatively, that this coinage reform was an ideological compromise forced upon the Caliph, "We can only guess what forces caused 'Abd al-Malik to drop his own image and titles from the coinage in favour of religious inscriptions that proclaimed the centrality of Muhammad and omitted all mention of the Caliph, but - purely numismatic considerations aside - it is difficult not to see this as an ideological compromise that was forced upon him", Johns, 2003, 433, which is essentially a much cited restatement of Oleg Graber's position, 
offering no explanation, just that change occurred for some 'ideological reason', and, in any case it is perhaps worth noting in respect to Johns' remarks, that the Caliph's name and titles do not in fact appear on these Standing Caliph dīnārs. This was, it is suggested below, a part of the problem that led to the issuance of the reformed-purely epigraphic currency).

It can be suggested that this change from the issuance of a figural to a non-figural coinage can best be understood as being a direct consequence of the issuance in gold of this particular depiction of the standing figure with a sword in a scabbard on the first Islamic coinage, an Islamic coinage (That 'Abd al-Malik was said to be responsible for the first issue of 'good' coinage,' that is carrying an Islamic inscription on gold and silver emissions, is recorded by alBaihaki in his Kitab al-Mahasin wa'l-Masawi, citing Al-Kisa'i's account of a conversation with the Abbasid Caliph Harun al-Rasid: "Do you know who originated this custom of the inscriptions on gold and silver?' 'Yes, my lord, I replied'. 'It was 'Abd al-Malik ibn Marwan', 'What was his reason for doing so?' he said. 'I do not know, apart from the fact that he was the first to institute this inscription' was my reply" quoted in, Serjeant, 1972, 12-13, by alBaladhuri, by at-Tabari and by ibn Khaldun; "According to reports, 'Abd al-Malik ordered alHajjaj to coin dirhams, and bad coin (began to) be distinguished from good ones” Khaldun, 2005, 217, with 'bad coin', not necessarily meaning thereby clipped or of substandard weight, but rather, not dedicated through the inscriptions it carried to the religion, and therefore being the currency of the unbelievers, although the use of this 'bad coin' was the practice of the Prophet Muhammad during his lifetime, of the Companions and of the Muslim community, until the subsequent innovation of the issuance of a Muslim coinage. The word 'tayyib'-good, appears in kufi script on some of the earliest Arab-Byzantine copper coins minted at HimsEmesa, stating the coin was good, presumably meaning minted by Muslims, and predating 'Abd al-Malik's reign) insofar as both the legend and the figures-symbols on obverse and reverse can no longer to be as obviously associated with Christian nomisma models as were the earliest examples of Arabic-Byzantine pre-reform coinage, through the Arabic Kufi script, and the legends employed, which clearly relate this coinage to Islam, and because this standing figure is not a copy of either an East Roman or a Sassanid model, and because it was an image issued in both the east and the west, struck in both Iraq and Syria. Emperor Justinian II (r. 685-95 and Rhinotemetus from 705-11) in response to the initial issues of coinage struck by the new religion carrying in Arabic the Muslim profession of faith and with the removal of the arms of the Christian cross (Heidemann, 2010, 28-29) on otherwise East Roman types of currency, the 'Arab-Byzantine' coinage, thereby dissociating it from Christianity and its symbols, and in particular, removing the arms-wings from the 'victory bringing cross' (Barber, 2002, 88-9. The removal of the arms from the cross, converting it into a staff - spear - or as an upright marker, possibly serving as an indicator of the direction of prayer, as in the vertical band in some later mihrabs such as that of the Khassaki Mosque of $8^{\text {th }}$ c. Iraq; Brend, 1991, Fig. 10, and possibly understood as representing the sirāt al-mustaqìm of the Fatiha, although see Heidemann, 2010, for the marker interpretation. The importance to the East Romans of the image of the cross during the subsequent iconoclast controversy to both parties is clear, see for example, Barber, 2002, 90-105), within the context of the battle fought over meaningful symbols between East Rome-Rum and Islam for the definition of the new religion as being distinct from, and not just a new, expanding and heretical sect of Christianity (Regarded as such by Christian figures such as John of Damascus (c. 675-749), who regarded Islam as a form of schism from Christianity, a Christian heresy rather than a different religion, see for example, H. Kennedy, The Great Arab Conquests, Phoenix, London, 2008, 362, 'There are no discussions of the new religion of Islam and its doctrines...For the Christians of the Fertile Crescent, the coming of the Arabs, and their 
apparently inexplicable victory, must be the result of God's wrath and the cause of that wrath was, above all, heresy.'; as also, Hanson, 2000, 57, "It was also Islam's often perceived status as a Christian heresy that made this religion particularly insidious and hateful". From the time of John of Damascus onwards this was a view of Islam common well into the Medieval period in Latin Christendom. As also the contemporary Christian references to the Muslims as the descendants of Ishmael, and so regarded as an instrument of God, as in the late $7^{\text {th }}$ c. Apocalypse of the pseudo Methodius,

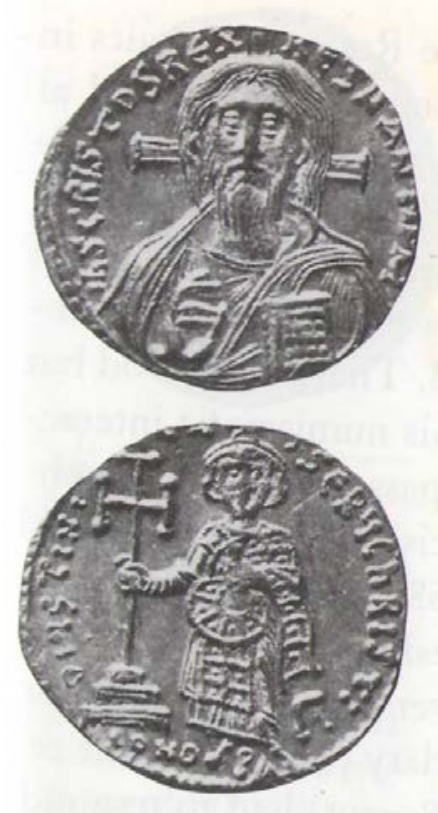

Fig. 4. 692 Christ Pantocrator and reverse, Justinian II with Cross. From R. Cormack, Byzantine Art, OUP, 2000, fig. 47. therefore, in East Roman eyes implicitly, if unconsciously, thereby acknowledging East Roman legitimacy and acknowledging that they were members of the Christian community, seems perhaps in part to have responded to these changes with the changes that he made to both the appearance and to the meaning carried by the East Roman coinage, changes made in the concluding year of the Quinisextum Council of the Eastern Church of 691-2, which, in its eighty-second canon established an equivalence between Holy words and Holy icons (See Barber, 2002, 79).

It seems evident that the outcome of the Quinisextum Council in respect to icons was a primary reason for the change which was made to the obverse face of the East Roman coinage in 692. Emperor Justinian II within this climate established by the Quinisextum Council in respect to icons, seems in part to have replied to this act of public disassociation of Islam from Christianity through the removal of the arms of the cross, by for the first time placing his own image, standing and holding the cross upon the reverse face of his gold solidus coinage, the obverse of the solidus had formerly always carried the image of the Emperor, and he placed for the first time an image/icon of the bust of the bearded Christ Pantocrator on the obverse with the inscription: Jesus Christos Rex Regnantium, which was struck from 692 onwards (Fig. 4) 
(During his second reign a different younger looking image of the Pantocrater with a smaller closer cropped beard was struck on the gold solidus), and which in type resembles for example the $6^{\text {th }}-7^{\text {th }}$ c. icon of the Pantocrator in encaustic of the Monastery of St. Catherine, Mt. Sinai (Fig. 5) an image that seems in origin to be based upon the Mandylion miraculously made for the King of Osrhoene (later al-Ruhā', Edessa, Urfa), Abgar the Black, and it was this image on cloth when discovered by the Bishop of Edessa with the letter from Christ, that was said to have defended the city from the Persians in 544, and this image was doubtless chosen for these same apotropaic reasons by Justinian II, given the rapid territorial advance of Islam including the siege of Constantinople 674-8, in the course of just thirty years from 632 to 692, the 'Napkin of Isa' was finally surrendered to Romanus I Lecapenus in 944 in exchange for Muslim captives and the lifting of the siege of al-Ruhā'/Edessa and which was received in a "unique religious festival" at Constantinople on the $15^{\text {th }}$ of August 944 (Ostrogorsky, 1991, 277-8. For the Napkin of Isa, see, le Strange, 1905, 103-4, fn. 1). While the inscription around this image: Jesus Christos Rex Regnantium, "The Lord Jesus Christ, The King of Kings”, can perhaps best be understood as being Justinian's response to the declaration of faith in Islam, "In the name of God. There is no god but God alone. Muhammad is the messenger of God." on the copies of East Roman coins, the Arab-Byzantine coinage, struck pre 692. bak, the legend 'Abd al-Malik, Commander of the Faithful beside the figure. From T. Falk, Treasures of Islam. Exh. Cat., Geneva, Phillip Wilson Pub., 1985, 379.
Fig. 6 Struck in Ba'al-

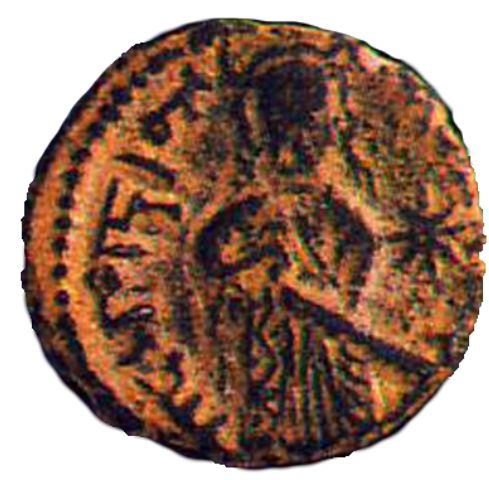

It was however within the tradition of the earlier pre 692 East Roman coinage that the Caliph, 'Abd al-Malik had placed the depiction of a standing human figure bearing a sword in a scabbard on the obverse of his dīnārs, with the earliest issue of these dīnārs dated to 74 A.H. / 693-694 A.D., and this image was struck on the silver dirham, possibly first minted in 72 A.H. in Iraq. This figure is generally understood to be a

representation of the Caliph himself, with these coins known as the 'standing caliph' coins, as some few examples, such as the fulus minted in copper at Ba'albak, carry the legend around this same standing figure with the sword reading: “'Abd al-Malik Commander of the Faithful” (Fig. 6), with the shahadah in these few examples struck not on the obverse but on the reverse of the coin (Falk, 1985, 379; Hitti, 1991, 218, and on others minted at Hims).

Clearly during the time these coins were struck between 72 and 77 A.H. the Caliph 'Abd al-Malik saw no theological contradiction in circulating these coins carrying his own image, nor between the two statements on the obverse of his dīnārs, one visual, a portrait of himself as Caliph, and the other in Kufi script in the margin around his portrait, the Profession of Faith in Islam. The Caliph thereby drawing a clear distinction through the striking of this image on these coins, consciously or otherwise, between making and circulating on the coinage an image/ portrait of a living person, the ruler, himself, and associating his own

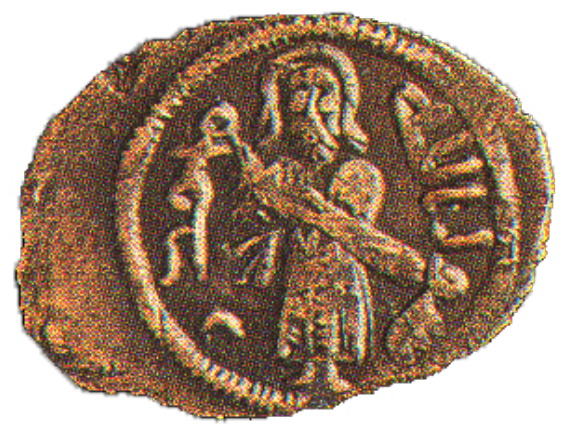

Fig. 7. Struck in Filistin, legend, Muhammed resul Allah around the figure. From T. Falk, Treasures of Islam. Exh. Cat. Geneva Phillip Wilson Pub., 1985, 377. 
image with the profession of Faith in Islam, and the entirely different matter of making an idol. This was the considered action of a thoughtful, austere Caliph who had been born and brought up in Medina by his father and where he would have been aware, born in 646, of eye witness accounts concerning the life and actions of the Prophet $\mathrm{d}$. 632 within religious circles in the city which he frequented.

However, the vast majority of these "standing caliph" coins invited the serious question, not of precisely who was depicted, for this standing figure with a sword was certainly intended by the issuing authority to be understood as being a depiction of the Caliph 'Abd al-Malik, the depiction of the Caliph replacing on the coinage the depiction of the East Roman Emperor, but, and much more importantly, given the fact that none of the dinnārs, nor the vast majority of the surviving copper fulus which carry this image of the "standing caliph" on the obverse, actually carry the legend, "'Abd al-Malik Commander of the Faithful” around this figure, the question would inevitably have been raised, as to precisely who or what this image of a single standing figure with a sword in a scabbard was meant to represent, by his contemporaries, both the Muslim minority and non-Muslim majority, using or seeing examples of this new coinage.

This is firstly because of the unprecedented change which had been made to Emperor Justinian II's coinage in 692, changing the assumption that the figure on the obverse of the coinage always depicted the Emperor, this change to a centuries old tradition, of course raised the question at this time as to exactly who or what was depicted on the obverse of this new Islamic coinage. And, secondly, because this figure on the obverse is most frequently surrounded by the legend "Muhammad Rasulullah - Muhammad Messenger of God", part of the shahadah, struck for example in Iliya-Jerusalem, Filastin-Palestine (Falk, 1985, 377), Fig.7, and a similar standing figure with a sword in a scabbard on the obverse and carrying the legend, "Bismillah Muhammad - In the Name of God (and) Muhammad", struck for example in al-Ruha-Urfa-Sanliurfa (Falk, 1985, 378) Fig. 8, as well as on the dīnārs, but which nowhere, either on the obverse or the reverse carries the name of the Caliph, but which does carry the name Muhammad in the legend around this standing figure, it being in the second part of the shahadah Figs 1-3.

It seems entirely probable, given the usual legend found around this figure, the shahadah, or a part thereof including the name Muhammad, combined with the fact that this was often in the case of some fulus, exactly the same legend around this standing figure on the obverse that reads: "Muhammad

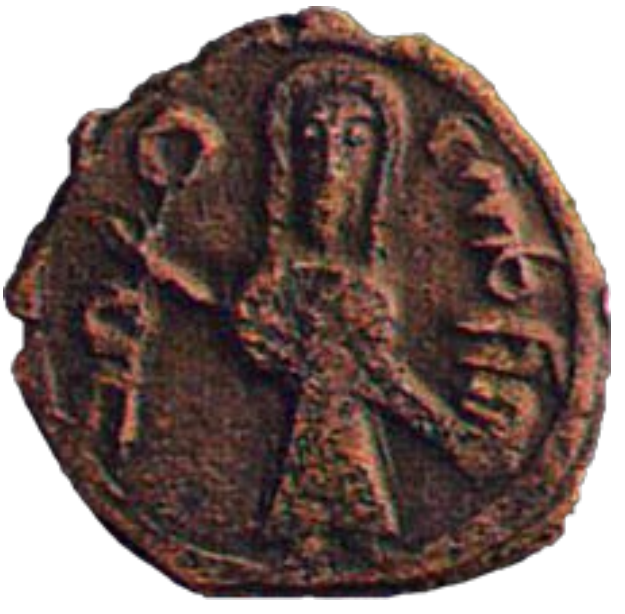

Fig. 8. Struck in al-Ruha, with Bismilla Muhammad around the figure. From T. Falk, Treasures of Islam. Exh. Cat. Geneva Phillip Wilson Pub., 1985, 378.

Rasulullah", (Fig. 7) as was known and was recorded as being inscribed on the Prophet's own seal ring (At-Tirmidhi (d. 892) Commentary by Shaykhul-Hadith Maulana Muhammad Zakariyya Muhajir Madni (87) Hadith No. 6 "Anas relates that: The Prophet Muhammad had an intention to write letters to Kisra, Qaysur (Caesar) and Najashi, inviting them to accept Islam. The people said: '(O Rasulullah) those people do not accept letters without a stamp on it'. For this reason the Prophet had a stamp made. The ring (loop) of which was silver, and had 'Muhammad Rasulullah' engraved on it". For the later copy of the Mühr-ü Saadet in the Topkapi 
Saray Museum's Mukaddes Emanetler Dairesi, inscribed in Kufi script on a red carnelian gemstone, which was made by order of the Caliph Othman (644-56) and which is today in the Topkapi Palace, Inv. No: 21/167, carrying this same inscription, see: Öz, 1953, 28; Uzunçarş1l1, Topkapı Sarayi Muzesi Mühürler Seksiyoni Rehberi, 1959, 1; photographed in colour in, Aydin, 2004, 101), as ibn Khaldun writes: "Thus, he took a silver seal (ring) and had the following legend engraved upon it: 'Muhammad the Messenger of Allah (God).' Muhammad said no one else should use a similar legend" (Khaldun, 2005, 218), that this figure, which was certainly intended as a depiction of the Caliph, matching the pre 692 East Roman practice of minting coins with an obverse of a standing figure of the ruling Emperor and a legend carrying his name, and there are a few copper issues that do carry the name of the Caliph 'Abd al-Malik around this figure as noted above (Fig. 6), that this depiction of the standing figure with the sword would almost certainly have been understood by many at the time, recent converts (For recent converts see, Bulliet, 1994, 29-30) and the members of majority Christian communities in Muslim territory, given Justinian II's recent change to his coinage and the fact that the legend around this standing figure: the shahadah on the dīnārs, and frequently, "Muhammad Rasulullah Muhammad the Messenger of God" or, "Bismillah Muhammad - in the Name of God (and) Muhammad" on the copper coinage carrying this image, that this figure was, clearly, if quite wrongly, identifiable through the adjacent name Muhammad, and was therefore probably at times understood, not as being a depiction of the ruling Caliph 'Abd al-Malik, but was probably rather frequently understood as being an image of the Prophet himself. There is nothing in the depiction of the face, hair, garments or sword scabbard to clearly indicate from the accounts of the appearance of the Prophet in the surviving hadith literature that this was not a depiction of the Prophet himself, including the hair twisted into thin dalik/plaits, although the hand on the sword while giving the Khutbah, as this image may possibly depict, was more a feature of the early Caliphs when giving the Jumah/Friday Khutbah than of the Prophet (Burton, 1964, II, 226, fn. 3). The alternative interpretation, even more shocking to Muslims today, was that this figure was understood by some Christians to be a Muslim depiction of an image-idol of the Almighty, given that Allah is the only other name that is recorded in the legend surrounding this figure on the dinars, and it is recorded three times, while the Prophet's name is recorded once.

That this figure was thought by some to represent the Prophet, by some the Almighty, seems more particularly to have been the case within the context of the battle over the symbols and legends-tîr $\bar{a} z$ on the coinage, as also most probably over the identifying $t \bar{t} r \bar{r} z$ inscriptions on other products (Recorded by al-Baihaki in his Kitab al-Mahasin wa'l-Masawi, “The paper (papyrus) was stamped (tarraza) in Greek with the inscription (tīrāz), "Father, Son, and Holy Ghost." Thus it continued as it had been, during the early period of Islam, until 'Abd al-Malik came to the throne, and noticed it, being of quick perception. One day he ('Abd al-Malik) was busy when a paper passed under his hands and he looked at the tīrāz on it and ordered it to be translated into Arabic, which was duly done. It displeased him, and he said, "What a very disagreeable thing it is for the faith and Islam, that this should be stamped on the paper and that it should be born on the pottery (awani), and the garments (thiyab), which, both are made in Egypt, and the other things made in that country, such as curtains (sutur), etc., which bear the tîräz on account of its (Egypt's) extent and abundant wealth. Its inhabitants produce this paper and it's distributed to all regions and countries with a heathen stamp emblazoned on it." 'So he ordered a letter to be written to 'Abd al-'Aziz ibn Marwan, who was the governor of Egypt, to cancel tīrāz on the garments, paper, curtains, etc., which used to bear it. He was also to make the manufacturers of paper, stamp it with the "Chapter of Unity" (Sura 112) "God 
testifies that He is God alone." This is the tīräz of the paper only (or specially), unto this day, neither more nor less, nor altered in any way. He wrote to all the governors of all the regions to cancel all the paper stamped with the Greek stamp in their province, and to punish those who were found to have any of it in their possession after the prohibition, with severe chastisement and lengthy imprisonment.", quoted in, Serjeant, 1972, 12-13), between the East Romans and Islam that began before the Battle of Sebastopolis in Cilicia in 692, which ended a military campaign the immediate cause of which was Emperor Justinian's transfer of Romans from neutral tax shared Cyprus to Cyzicus due to their maritime tradition, over the protests of the Caliph 'Abd al-Malik, where the East Roman forces led by the professional soldier and future Emperor (r. 695-8) Leontios were decisively defeated by the Caliph's forces, following the defection from the East Roman army of a large contingent of resettled Slav troops (Ostrogorsky, 1969, 131. Leontis was imprisoned after his defeat and became Emperor in 695 with the fleet sent under the patrician John sent to recapture Carthage by the Emperor Leontis (695-8). It was retaken by the Muslims in 698); but which had its root in the matter of the Jarajimāh/Mardaites, Justinian's threat and his use of them in 689 as proxies in Syria and of the consequent tribute of 1,000 dīnārs a week paid by the Caliph for their quiescence (For example, Ostrogorsky, 1969, 131-2; Hitti, 1991, 204-5); given that prior to the emission of the "standing caliph" dīnār in 6934, Justinian II had placed the depiction of Christ, Pantocrator instead of the Emperor on the obverse of his coins struck from 692 onwards (Fig. 4), and so it seems therefore quite conceivable that this new image of the "standing caliph" type on dinars issued after the Battle of Sebastopolis was understood by the East Romans as being a depiction of the Almighty, and was understood by them as being the Caliph's response to the Emperor's minting of the image of the Pantocrator, an icon of Christ, on the obverse of the Empire's solidus. So these new dinnars of the "standing caliph" type could have been understood by the East Romans as the Caliph's response to this new East Roman coinage, understood that is, following the Muslim victory at Sebastopolis, as carrying on their obverse a Muslim icon of victory, depicting the Almighty with the sword.

It seems to this author most probable that the change in 77 A.H./ 696-7 A.D. under the Caliph 'Abd al-Malik to striking dīnārs with solely inscriptions and carrying no standing figure with sword or any other figural depiction, of a different lighter weight, the mithqal, $4.25 \mathrm{gm}$, less than the solidus, and which are today termed the 'reformed' coinage (Fig. 9), the coinage of L. Treadwell's 'Epigraphic Phase' (Treadwell 2009, 362), was therefore made not primarily to distinguish the currency of the Islamic Caliphate from other coinage through emphasising the Word to the exclusion of the image. This, although it was later understood by many, today, as in the past, including ibn Khaldun and his sources to have been done for this reason. Ibn Khaldun wrote: "He ('Abd al-Malik) used an iron stamp, but engraved words on it, rather than pictures, because eloquent words were obviously more congenial to the Arabs. Moreover, the religious law forbids pictures" (Khaldun, 2005, 217).

However, ibn Khaldun and his sources clearly failed to realise, or they did not choose to record, that the Caliph 'Abd al-Malik was quite content to have his own image struck on these dinnārs over the course of four lunar years, where his image had replaced that of the East Roman Emperor, not, as ibn Khaldun writes: "When Islam appeared, the practice (of striking images on the coinage) was discontinued, because of the simplicity of Islam and the Bedouin attitude of the Arabs" (Khaldun, 2005, 217); while the most ample surviving and recorded evidence clearly indicates that 'pictures'- images were common at this time, the hadith material from which to form legal rulings, 'the religious law' mentioned by ibn Khaldun in the 8 th $/ 14^{\text {th }} \mathrm{c}$. on this matter of the lawfulness of images was hardly in existence until the second century after the hicra and 
later (For the second century hicra date see for example: Hallaq, 2009, 45-46, 49, at the time of the victory of hadith over sunnaic practice; also, Goldziher, 1971, 42-46), and so anti-figural hadith could have had no possible currency or traction with those in power at this early date in respect to the depictions of both animate and inanimate things on the coinage or anywhere else, these legal rulings as such were simply not in circulation at this time. This same misconception made by ibn Khaldun and his sources is made by others today for this same reason (Khaldun, 2005, 217), when combined with the fact that the use of the Arabic script for the coinage and for other official purposes is dated to A.H. 72/692 A.D. (Blair, 1998, 21), with the change in the official script for the diwan registers to Arabic from Greek and from Persian in this same year ("Thus, 'Abd al-Malik ordered Sulayman b. Sa'd, then governor of Jordan province, to introduce the use of Arabic in the diwan of Syria. Suleyman completed the task in exactly one year to the day. Hajjaj ordered his secretary Salih b. 'Abd-ar-Rahman to introduce the use of Arabic, instead of Persian, in the diwan of Iraq. Salih knew how to write both Arabic and Persian" Khaldun, 2005, 199), the year of the execution of 'Abdullah ibn az-Zubayr and the reunification of Caliphal territory and authority under 'Abd al-Malik, which these changes, together with the first issue of coinage carrying this figure, the dirhams struck in Iraq on behalf of 'Abd al-Malik by Al-Hajjaj ibn Yusuf, marked. It is clear however, that apart from on the post reform coinage struck from A.H. 77 onwards (Fig. 9), the employment of figural images over a wide range and scale of objects and surfaces both continued and increased in quantity (for references see above), images both sponsored and used by Omayyad Caliphs, including those images recorded in mosaic, on metalwork (Figural works were used in early mosques, prior to the late $8^{\text {th }}$ c. introduction into them of aniconism, eg. the Caliph Omar (634-44)'s use of a figural censer to perfume the Medina mosque, Arnold, 1965, 7, for other examples, idem 8; as well as the figural works painted on the columns in the Ka'ba that remained in place until the fire of 683 and the demolition of the remains in 684 by Ibn az-Zubayr etc.), and in sculpture, such as the life-sized stucco portrait sculpture of a Caliph which survives from Khirbat alMafjar (Fig. 10), as also statues of princes and concubines (For illustrations of these, see for example, Graber, 1987, Figs. 79-84), together with the images that were painted on the walls of mosques (For example, Naser-e Khosraw in 1051 while in Falaj painted in red and blue paint in the mosque a branch with leaves growing up through a line of poetry, and then he painted the mihrab of the mosque for 100 maunds-159 kilos of dates, Naser-e Khosraw's Book of Travels (Safarname), 1986, 85), as well as painted on stonework (Naser-e Khosraw's Book of Travels (Safarname), 1986, 9, records of the congregational mosque in Amed-Diyarbakr, "All the roofs are peaked, and all the masonry is carved and painted with designs"), and upon other buildings.

Rather, it seems more probable that this reform of the new Islamic coinage during the latter part of 77 A.H. was carried out to prevent the probable misunderstanding caused by this depiction on the obverse of the coinage of the image of the ruling Omayyad Caliph, the Commander of the Faithful (The Omayyad far more encompassing title, Khalifat Allah, see, Black, 2001, 18-19; Bosworth, 2004, 4, was only employed on silver issues, see Treadwell 2009, 370), being mistakenly understood by some as being a depiction of the Prophet himself, or, and far worse from the Caliph's perspective, being understood by some others as being a depiction of an Muslim idol representing the Almighty, and so, being in effect, although not in intent, understood as being an idol-icon (For the definition of what the contemporary John of Damascus meant by the term, icon, see Barber, 2002, 76), that is like the image of the icon of the Pantocrater struck on the obverse of the new East Roman emissions from 692 onwards. 
It seems probable that it was to prevent this confusion concerning both the identity and possibly at the time more importantly, the perception of the function of this figure on the coinage, the question of was it the Caliph, was it the Prophet, or was it an image-icon of the Almighty, and so was it to be understood as representing a Muslim idol-icon (There may be some possible trace memory of this image struck on the coinage in the surviving accounts of portraits being made of the Prophet, as also in the false idea that Muslims worshipped an image of the Prophet), - the worship of anything other than the Almighty, including the worship of idols and images is of course for any Muslim shirk, the act of associating partners with the One and which is the one sin that will certainly not be forgiven by the Almighty (Idolatry in its varied forms is explicitly and repeatedly forbidden in the Holy Koran as the one sin that the Almighty will not forgive, Sura 4, Al-Nisa, 116; and that "Idolatry is worse than carnage", Sura Al-Baqarah, 2: 191-4; also Sura Al-Ahqaf, 46: 5; Sura Al-Nahl, 16: 20-21 and 73; and Sura AlA'raf, 7: 190-200), - that the currency reform of A.H. 77/696-7 A.D. intended to remove, and which it successfully eliminated, by removing the source of this possible confusion, through eliminating figural images, but only from the coinage, firstly with the dīnārs carrying this image withdrawn from circulation, whilst otherwise figural works in both two and three dimensions continued to be produced in quantity under the Omayyads, as later under the Abbasids, including: the striking of figural medallions as noted above, paintings, figural miniatures, relief and free-standing sculptures, sculptural automata and figural images on seals.

Further, it seems at least possible to suggest that perceptions amongst pious Muslims concerning the identity of this figure on the coinage may have lent at least some additional support to anti-Omayyad polemics and to the description of the Omayyad Caliphs as malik and of 'Abd al-Malik b. Marwān subsequently described by the laqab, al-Mulük-father of kings, father of the Caliphs: al-Walīd, Sulayman, Yazīd II and Hishām, and of the conversion of the khilafat al-nubu'ah, the theocratic Caliphate, into a mulk, a temporal sovereignty (For example, Hitti, 1991, 197), through this substitution of the image of this Caliph for the image of the East Roman Emperor on the coinage.

It therefore seems reasonable to suggest that the root of the problem in respect to the Muslim perceptions of this image lay in the particular combination of the shahadah or a part thereof, or other legend mentioning the name of the Prophet, when it was combined with the depiction of the ruling Caliph but without the Caliph's image being named, on the obverse of this coinage, leading to the suggestion it was the Prophet rather than the Caliph that was depicted; together with the fact of the substitution of the depiction of the Caliph for that of the East Roman Emperor, and so suggesting to some Muslims some equivalence between them.

The image of the Caliph was placed on the obverse because it replaced the expected image of the Emperor which was standard on the obverse of East Roman currency until 692 and was sunna, insofar as it was of the same type of coinage as that which was used by the Prophet during his lifetime; while the name of the caliph was omitted from the obverse legend around this figure if the shahadah, or a part thereof, or the name of the Prophet surrounded this figure, thereby ensuring that the fundamental declaration of faith in Islam was not attached to the name of this particular Caliph.

The solution to the confusion caused concerning the identity of this depiction was to ask the question, which was more important, the legend recording the Profession of Faith containing the Name of God and of the Messenger, or the image of the latest of the Messenger's successors, and the answer was given by the Caliph 'Abd al-Malik in the reformed coinage issued from A.H. 77 onwards (Fig. 9). 

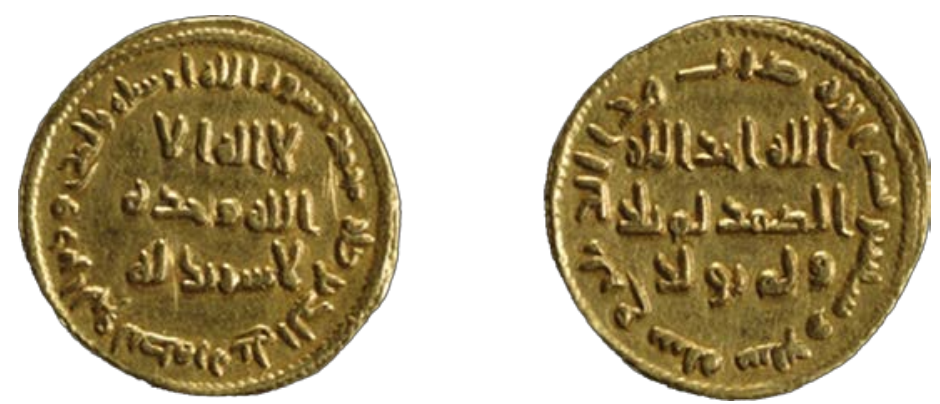

Fig. 9. Reformed dinar dated A.H. 77- 696-7 A.D. CM 1874,0706

This reform made to the new Islamic coinage, from carrying both images and inscriptions to a coinage carrying only inscriptions could have been regarded as bida, that is, the sin of innovation away from the sunna, against the practice established by the Prophet of using a coinage which carried both images and inscriptions, innovation (Reprehensible innovation bida, is condemned in a variety of hadith, eg, Riyad us-Saliheen, Imam an-Nawawi, "On the authority of Yazid bin Sharik bin Tariq...Those who innovate in this territory new ideas in Islam, commits a sin therein. Those who shelter innovators will incur the curse of Allah, the angels and all the people. Allah will not accept his obligatory or optional service on the Day of Resurrection...” No 1804 Nawawi, Imam Abu Zakariya, 1993, 275; likewise, Jabir relates:...He would point out: The best discourse is the Book of Allah and the best example is the example of Muhammad; the worst practice is the injection of new elements into faith, and every innovation is misguidance...”, No. 171 in, Imam Nawawi, 1989, 44. The ramifications of this seeming bida innovation, the removal of figural images from the coinage, were of course of considerable later importance in respect to attitudes of some Muslims towards figural art) but this seems not to have been the case, or is not present in the surviving record.

\section{The Timing}

However the reason why figural images were removed from the currency by 'Abd al-Malik during the year 77 A.H., after striking from 72 A.H. onwards over the course of more than four years this image on the coinage on dirhams and fulus and then dīnārs, some considerable number of which reached East Roman hands as tribute, is presently somewhat obscure, but it is evident that this image until 77 A.H. was intended to be, and it was for the dīnār, the standard obverse image on the coinage of the reunited Caliphate.

It seems most probable that it was a consequence of diplomatic and perhaps other contacts with the East Romans, culminating in a mission that arrived during the course of 77 A.H., which resulted in this sudden and most remarkable coinage reform of 77 A.H., and this seems to have been a consequence of the Caliph being made aware that his image on this coinage, was not only being mistaken by some for being an image of the Prophet, which would doubtless have been understood by him as being a very great compliment indeed, if incorrect, but instead, incredible though this may seem have seemed to him then, and to us today, that it was being understood by the East Romans as being an image that they thought depicted a Muslim idol of the Almighty (It is possible that this image of the Caliph with the prominent sword may also have been misunderstood by some Orthodox Christians who regarded Islam as just another Christian heresy as being a depiction of Christ bringing the sword to the world, as in Matthew 10.34, "Think not that I am come to send peace on earth: I came not to send peace, but a 
sword") which was being struck on the obverse of this new Islamic coinage, like the image of the Pantocrator on the obverse of the new East Roman coinage. To have ones image mistaken for that of the Prophet is of course one thing, to follow the example of the Prophet was and remains sunna for Muslims, but to have ones' own image mistaken for being an image depicting an idol of the Almighty, that was something else entirely, and was of course absolutely unacceptable to the Caliph 'Abd al-Malik.

If, and it seems reasonable to suggest that this allegation was almost certainly made by the East Romans and news of this allegation and of the associated East Roman threat reached the Caliph in Damascus during the course of 77 A.H./696-7 A.D., then this image certainly had to be removed by 'Abd al-Malik from the coinage, as the Almighty can be named in words and script but certainly cannot be depicted or be understood to have been depicted as an idol, a sculptural-pictorial image of the Almighty, forming a circulated image of what was thought by the East Romans to be the idol of the Muslims struck on the coinage of the Caliphate. It was therefore absolutely impossible for this misunderstood image to remain on the new coinage of the reunited Omayyad Caliphate, the Holy Koran clearly records idols are an abomination devised by Satan (Holy Koran, Sura Al-Ma'idah (The Table) 5:60, "Believers, wine and games of chance, idols and divining arrows, are abominations devised by Satan"), and it can be understood that it was for this reason, to prevent this very great misunderstanding in regard to the identity of this image on the coinage in the eyes of the East Romans that 'Abd al-Malik's reform of the newly issued Islamic coinage in 77 A.H. took place.

It seems a somewhat tangled account of this process actually survives in the report dating from the reign of the Abbasid Caliph Harun b. al-Mahdi, Abu Ja'far al-Rashid (786-809) that was related by Al-Kisa'i and survives, recorded at the latest in the first decades of the $10^{\text {th }} \mathrm{c}$. by Ibrahim b. Muhammad al-Baihaki concerning the reason why 'Abd al-Malik reformed the currency: “...the Caliph ('Abd al-Malik) refused the Emperor (Justinian II)'s request three times (to return to the Greek tīrāz of "Father, Son, and Holy Ghost." Which the Caliph had replaced with the tīrāz of, "God testifies that he is God alone." citing from Sura Samad - Al-Ikhlâs - atTawhid 112 ), until he (the Emperor) threatened to stamp a phrase containing an imprecation of the prophet on the Byzantine coinage which was used in Muslim countries also, for they lacked a good currency of their own. 'Abd al-Malik replied by instituting the new coinage" (Serjeant, 1972, 13). It would seem from this account that three separate envoys, presumably with the rank of magistianus from the office of the magister officorum, had been sent from the Emperor to the Caliph demanding the return of the Trinitarian $t \bar{t} r \bar{a} z$ to the coinage in the period between 72 and 77 A.H. and presumably Justinian's threat to: 'stamp a phrase containing an imprecation of the prophet on the Byzantine coinage,' concerned not only the matter of the tīrāz inscription but also the matter of this figure on this new Islamic coinage being understood by the Emperor as being a depiction of the Prophet or of the idol thought to be worshipped by the Prophet Muhammad and the Muslims. By the late $8^{\text {th }} / 9^{\text {th }}$ c. it seems that knowledge of the Islamic figural issues struck until 77 A.H. had been lost, or this fact was then unmentionable, and so Al-Kisa'i relates that: 'Abd al-Malik replied by instituting the new coinage (that is the reformed coinage carrying only inscriptions)' issued he says in response to the East Roman threat concerning the changes 'Abd al-Malik had made to the tìrāz on Egyptian paper (papyrus) in 72 A.H., rather than it being in fact the response to the changes 'Abd al-Malik had made to the coinage, as also to other tīrazz inscriptions and to the script employed in the diwan in 72 A.H. Although R. B. Serjeant is somewhat sceptical of this account in respect to the tīrāz, 'Very little reliance, then, must be placed on this passage of Baihaki, which smacks more of legend than actual fact" (Serjeant, 1972, 13), D. Fairchild-Ruggles suggests 'a believable account' (Fairchild-Ruggles, 
2011, 57) is provided by Bayhaqi in respect to the coinage and, with the above qualifications, it seems that perhaps this early $10^{\text {th }}$ c. account should be regarded with some greater degree of confidence than Serjeant awarded it, as it seems most probable that it was the last of these three envoys from the East Romans, bearing in addition to the demand to return to the Trinitarian $t \bar{i} r \bar{a} z$, this potent threat, that resulted in the removal of the image of the Caliph from his coinage, and which resulted in the issuing of the reformed coinage during 77 A.H./696-7 A.D. Theophilus of Edessa records in his Chronicle that in 697, "Justinian refused to accept the minted coin that had been sent by 'Abd al-Malik, because it was of a new kind that had never been made before". (Theophilus of Edessa, 2011, 190-91) that is, the newly minted purely epigraphic dīnārs of the reformed currency, of a different lighter weight that were sent as tribute payment by 'Abd al-Malik were rejected by Emperor Justinian II.

\section{The idol termed the God of Muhammad}

Further, it may well be the case that examples of this image of the Caliph 'Abd al-Malik struck on the coinage to 77 A.H., probably on the dīnārs that reached East Roman hands as tribute between 74 and 77 A.H., had some real relationship to the recorded East Roman description of the idol that was said to depict the Almighty and which was wrongly believed by Orthodox Christians to have been worshipped by the Prophet Muhammad and by Muslims, an idol which they termed the 'God of Muhammad', a description of which is contained in the widespread $9^{\text {th }}$ or possibly in origin $8^{\text {th }}$ c. Orthodox Christian "Formula of Abjuration" (Hanson, 2000, 60 and the references given in fn. 22, also, 61), employed in the process of conversion and reconversion, of admitting/readmitting apostate Muslims into the Orthodox Church. This formula records in its text:

"And before all, I anathematize the God of Muhammad about whom he (Muhammad) says, 'He is God alone, God made of solid hammer-beaten metal; He begets not and is not begotten, nor is there like unto Him any one" (Hanson, 2000, 55. My emphasis).

The text of this Orthodox Christian Formula of Abjuration, as has been noted by C. L. Hanson, contains a mistranslation of the word samad in Sura Al-Ikhlâs/Samad/at-Tawhid Oneness-The Eternal-The Unity, 112.2 of the Holy Koran (Also called, "Kul, Huw' Allah,”, Burton, 1964, 311), which should in fact read:

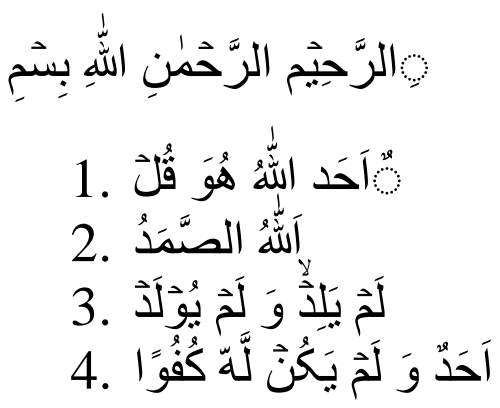

In transliteration: Bismillah ir-Rahman ir-Raheem 1. Qul huwa Allah hu ahad 2. Allah hu 'ssamad 3. Lam yalid wa lam yulad 4. Wa lam yakun lahu kufuwan ahad.

In translation: In the Name of God, the Merciful the Compassionate. 1. "Say: 'God is One, 2. The Eternal God. 3. He begot none, nor was He begotten. 4. None is equal to Him”.

The nominative masculine singular noun samad meaning Eternal was translated instead as

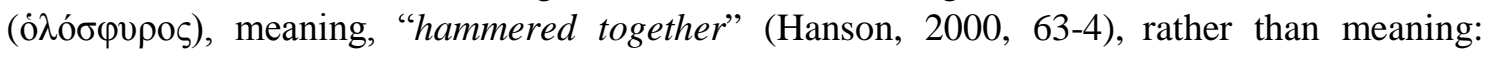


Permanent, Everlasting, Eternal (Translated as, 'the Eternal' in G. Sale's translation published in November 1734; as, 'The eternal God' by Sir R. F. Burton, Pilgrimage to Al-Madinah and Meccah, Dover, New York, (1893) 1964, I, 311; as, 'the eternally Besought of all!”; in M. M. Picthall's translation of 1930; as, 'the Eternal'; in Yusuf Ali's of 1934 as: 'the Eternal, Absolute'; in A. J. Arberry's translation of 1955: 'the Everlasting Refuge'; in Arthur Jeffery's 1958 selection; as, 'the Self-Existing and Besought of all'; in N. J. Dawood's 1974 translation; as, 'the Eternal' in his translation of 1990; as, 'the everlasting', in M. Z. Khan's 1981 translation; as, 'the Eternal.'; and in Turkish as, 'Allah samed'dir' by S. Ateş in the Kur'ân-1 Kerım ve Yüce Meâli of 1974; as, 'Allah her şeyden müstağnı ve her şey O'na muhtaçtır' in the Kur'ân-1 Kerim ve Türkçe Anlamı, Diyanet Işleri Başkanlığı Yay, of 1986; as, 'Allah sameddir' in the Diyanet Işleri Başkanlığg Yay. 590, H. Karaman, M. Cağici, I. K. Dönmez, S. Gümüş, Ku'ran Yolu Türçe Meal ve Tefsir, V. Ankara, 2008.). This word samad was mistranslated into

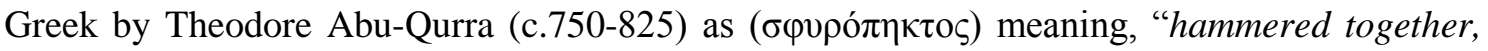
consolidated, indivisible" (Hanson, 2000, 62) and this word samad - meaning in this context Eternal, was then translated by the philosopher Nicetas of Byzantium in the mid- ${ }^{\text {th }}$ c. to

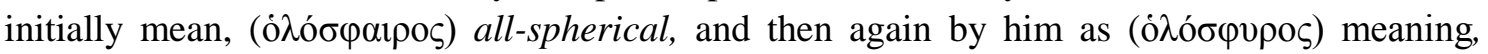
made of solid, hammer beaten metal (Hanson, 2000, 62), a translation of this word in this context which remained current for East Romans from the $9^{\text {th }} \mathrm{c}$. into the $12^{\text {th }} \mathrm{c}$. employed in this East Roman official Formula of Abjuration over the course of about 300 years.

This mistranslation of this word samad in Sura Samad/Al-Ikhlâs/at-Tawhid (A. Jeffery dates the revelation of this Sura as, 'An early Meccan Sura.' as likewise, M. M. Pickthall) may stem not only from a generalised Christian Orthodox incomprehension of and hostility to Islam, seeing it as a Christian heresy as noted above, but in some considerable part, from the genuinely held but wrong perception that this particular image of the Caliph 'Abd al-Malik which had been hammered into the obverse of this circular Islamic coinage, one may think did not, in East Roman eyes depict the Caliph at all, as, after all, the legend around this figure on these dīnārs does not record the name of the Caliph, but this tīrāz-legend-inscription does record the Name of the Almighty and of the Prophet Muhammad, and, in consequence, this image on these dinārs was understood by them to be a clear record of the idol of the God (which was) made of solid hammer-beaten metal, that is a representation of, the God of Muhammad, with this figural image of the Caliph wrongly understood by them to be an actual depiction of the Muslim idol of the Almighty, an idol they mistakenly thought existed, and which they thought was worshipped by the Muslims, an idol resembling the idols of Pagan idolaters, as had been initially suspected to have been the focus of Muslim worship during the lifetime of the Prophet by both Pagans and Jews (Reportedly cited by Ibn Taimiyyali in his commentary on Surah Al-Ikhlas; As when it is reported that Amir bin at-Tufail (d. 633) said to the Prophet prior to the revelation of Sura 112, Al-Ikhlâs/Samad/at-Tawhid: "O Muhammad, what do you call us to?" The Holy Prophet replied: "To Allah" Amir said: "Then, tell us of what He is made, whether of gold, silver, or iron?" While it is reported that Thabit bin Ad-Dahhak, Qatadah and Muqatil ibn Sulayman (d. 767) have stated that some Jewish rabbis came to the Prophet and said: "O Muhammad, tell us what is your Lord like, so that we may believe in you. Allah in the Torah has sent down His description. Kindly tell us of what He is made, what is His sex, whether He is made of gold, copper, brass, iron, or silver, and whether He eats and drinks. Also tell us from whom He has inherited the world, and who will inherit it after Him" following which the Sura 112, AlIkhlâs/Samad/at-Tawhid was revealed.), thought to have been an idol of Allah, possibly made of gold, silver, copper, brass, or of iron.

It seems therefore possible that examples of this figural issue together with memories of 
Justinian II's threat of 77 A.H. to: 'stamp a phrase containing an imprecation of the prophet on the Byzantine coinage', associated with this Islamic figural issue, may have influenced the

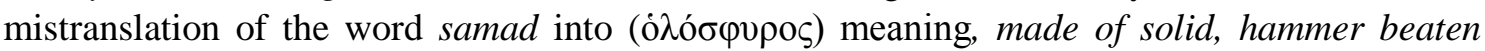
metal, as it seems this image of the Caliph 'Abd al-Malik on the coinage was genuinely mistaken by contemporary Orthodox Christians for being an actual depiction of the God made of solid hammer-beaten metal that they thought was worshipped by the Prophet Muhammad and by the Muslims, and this was logically, although wrongly understood in this way by them, as being like the image of the icon of the Pantocrator which was struck at times on the obverse of their own coinage following the Quinisextum Council and which was certainly understood by them to be an image of the member of the Christian Trinity, Christ, and this image-icon of Christ was in fact, and still is, worshipped-venerated by Orthodox Christians.

\section{The misunderstanding}

It would therefore seem that it was as a direct consequence of this most fundamental misunderstanding between the Muslims and the East Roman Christians concerning the identity and meaning of this particular image on this type of dinār, that the Caliph 'Abd al-Malik entirely removed images from the dīnārs struck from 77 A.H. onwards, eliminating the source of this confusion through the subsequent employment of only script on the obverse and on the reverse of the dinārs of the Caliphate. It is noteworthy in this context that it is the Sura Samad/Al-Ikhlâs/at-Tawhid (The Eternal-Oneness- The Unity) 1-4 that forms the text on one face of the reformed dīnārs, reiterating in quantity the fundamental theological distinction between Christianity and Islam, and which was also a feature of 'Abd al-Malik's earlier inscriptions in mosaic on the interior façade of the Qubbat al-Sakhra (Dome of the Rock) of 72 A.H. 691/2-695. The change from figural images to the Word on the coinage in 77 A.H. was, it is suggested here, made for these particular reasons at this particular time, and it seems to have been a direct consequence of the third and final mission that was sent by Justinian II to the Caliph, arriving in Damascus in 77 A.H./696-7 A.D. concerning this matter, which not only for the third time demanded the return of the Trinitarian inscription, 'Father, Son and Holy Ghost', to the coinage, to the state $\bar{t} r \bar{a} z$ inscriptions, which the Caliph refused, but which was also combined with the threat of striking 'an imprecation of the prophet on the Byzantine coinage.' The threatened curse presumably was related to what the East Romans perceived as Muslim idolatry and which was countered by 'Abd al-Malik through the recording of Sura Samad/AlIkhlâs/at-Tawhid (The Eternal-Oneness- The Unity) 1-4, on the reformed, epigraphic dīnārs.

It seems evident therefore that this 'reform' made to the new Islamic coinage was made for quite specific, particular reasons as indicated above. It was for these specific reasons rather than being a part of the series of changes that publicly disassociated and distinguished Islam from Christianity, as was later stated by ibn Khaldun (Khaldun, 2005, 217) and by others, in a process which began with the belief in the One Eternal God, not in the Christian Trinity, which is recorded in this same Sura Samad/Al-Ikhlâs/at-Tawhid (The Eternal-Oneness- The Unity) of the Holy Koran (Holy Koran, Sura Al-Ikhlâs/Samad/at-Tawhid (Oneness-The Eternal-The Unity) 112, "Say: 'God is One, the Eternal God. He begot none, nor was He begotten. None is equal to Him."), and that Christ was a Prophet, the servant of God (Holy Koran, Sura Maryam (Mary) 19:29-30, "She made a sign to them, pointing to the child. But they replied: 'How can we speak with a babe in the cradle?' Whereupon he spoke and said: 'I am the servant of God. He has given me the Book and ordained me a prophet'); who did not die on the cross (Holy Koran, Sura Al-Nisa (Women) 4:157, "They denied the truth and uttered a monstrous falsehood against Mary. They declared: 'We have put to death the Messiah, Jesus the son of Mary, the 
apostle of God', They did not kill him, nor did they crucify him, but they though they did"), followed by: the change in the Muslim direction of prayer from Jerusalem to Makkah (Holy Koran, Sura Al-Baqarah (The Cow) 2:142, "The Foolish will ask: 'What has made them turn away from their former qiblah?”, the former qiblah being Jerusalem, hence the Al-Kiblatayn Mosque in Medina.); the specific forbidding of the consumption of wine (Holy Koran, Sura AlMa'idah (The Table) 5:60, "Believers, wine and games of chance, idols and divining arrows, are abominations devised by Satan" Sarris, 2011, 261 citing from the near contemporary Christian post 660 A.D. Armenian History likewise specifically records the prohibition of wine: "So Mahmet (sic) legislated for them: not to eat carrion, not to drink wine, not to speak falsely, and not to engage in fornication"), as it was employed in the Christian sacrament of the Eucharist; the specific forbidding of the consumption of pork which was eaten by Christians, but not eaten by Jews (Holy Koran, Sura Al-Ma'idah (The Table) 5:3, "You are forbidden carrion, blood, and the flesh of swine; also any flesh dedicated to any other than God". Theophilus of Edessa, R. G. Hoyland, 2011, 189, records that 'Abd al-Malik ordered the slaughter of all the pigs in Syria in 694.); and the prohibition of celibacy, which was associated with Christian monkhood (Holy Koran, Sura Al-Hadīd (Iron) 57:28 "As for monasticism, they instituted it themselves (for We had not enjoined it on them), seeking thereby to please God; but they did not observe it faithfully. We reward only those who were true believers; for many were evil-doers"). Instead, this reform to the newly issued coinage was instituted at this particular time in order to prevent any further allegations of idolatry by Muslims being made by the East Roman Christians, an allegation which was based upon this particular image of the standing figure of the Caliph 'Abd al-Malik struck on the coinage throughout the Caliphate being misunderstood as being a depiction of a Muslim idol representing the Almighty.

\section{Some Consequences}

However, the consequences of this misunderstood image of the Caliph 'Abd al-Malik struck on the new Islamic coinage only during this brief period from 72 to 77 A.H. would remain and would continue to haunt relations between Islam and Christianity for centuries, through the continuing Orthodox and Latin Christians allegations that the Muslims worshipped idols, not only recorded through the mistranslation of the word samad and employed in the Orthodox Formula of Abjuration for 300 years as noted above, but also for example into the $10^{\text {th }}-12^{\text {th }}$ century in the west, as by Hrotswitha of Gandersheim who referred to Spanish Muslims worshipping idols of gold (Fletcher, 1989, 54. As also for example Helinandus of Frigidi Montis's Chronicon of 1212 which records that Saracens fabricate idols in the name of Mahomet, as earlier in the Song of Roland, XXXII, CCXXXV:

"That admiral hath great possessions;

He makes them bear before him his dragon,

And their standard, Tervagan's and Mahom's,

And his image, Apollin the felon (Apollyon/the Destroyer-Devil)”.

For Tervagant which is reported in Christian sources to be a, 'gold speaking Muslim idol', see for example, Akbari, Cornell University Press, 2012, 212-214), as in the, "Chanson de Roland" where it was written and recited that: "The Emperor (Charlemagne) has captured Sargossa and has the town searched by a thousand of his Franks. In the Synagogues and temples of Muhammed (Mosques), with iron clubs and hand axes, they smash Muhammed and all the other idols so that no devilry or superstition will remain". Some of the later allegations of Muslim idolatry doubtless sprang from some partial knowledge of Islamic automata (Duggan, 2009. The 
reverse allegations were stated to Doughty in 1876 in Kasr Zellum, Arabia, Doughty, 1990, I, 341, "The Nasāra worship idols, and this not only, but that they blaspheme the apostle", that is, insult the Prophet), but the start of these allegations of Muslim idolatry seems to have been related not only to the earlier Pagan and Jewish expectations that the Prophet worshipped a

metal idol, with these Pagan and Jewish expectations explicitly contradicted by the revelation of the Sura Samad/Al-Ikhlâs/at-Tawhid, and which formed a standard text on the reformed epigraphic currency, but also to late $7^{\text {th }}$ c. Orthodox Christian perception that this image of this Caliph struck at this time on this coinage was a depiction of the hammered metal idol that East Romans incorrectly thought was worshipped by the Muslims.

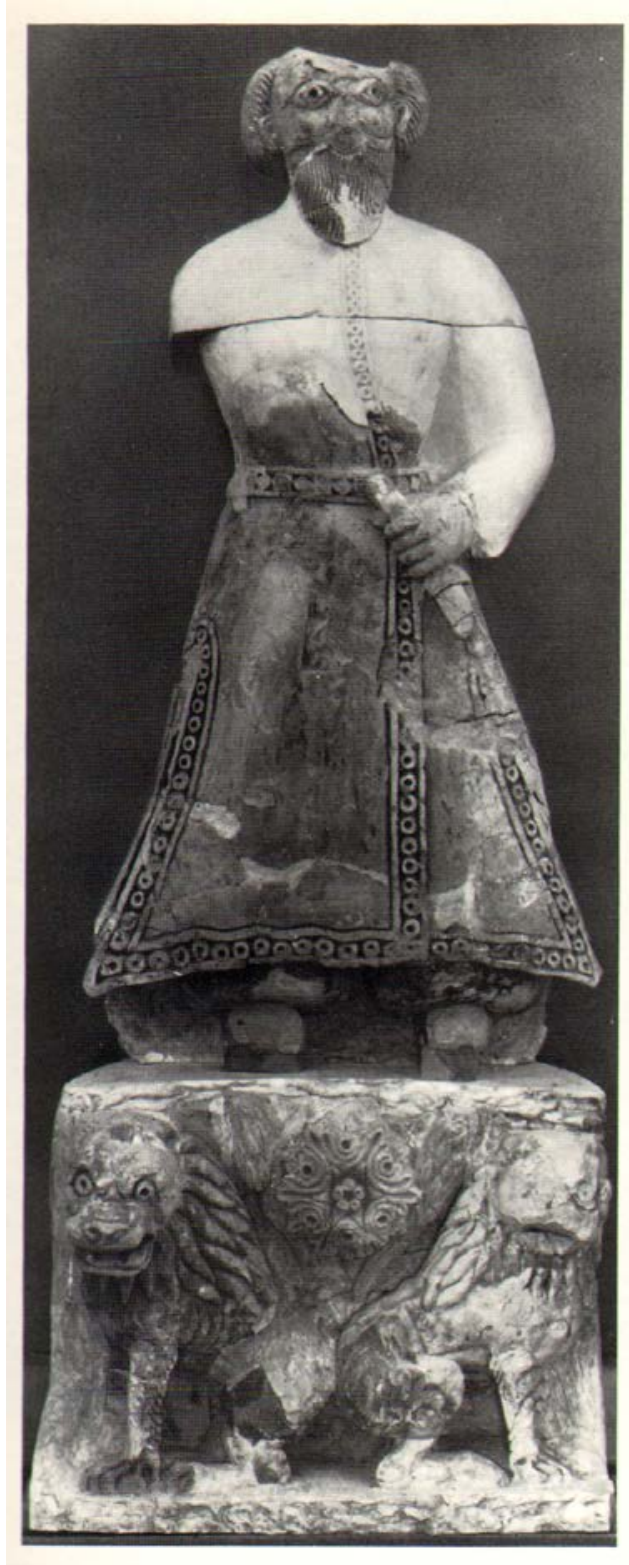

Fig. 10. Statue of a Caliph, probably Hisham, c. 724-43 from Khirbat al-Mafjar (from Graber 1987 Fig. 81).
The questions that were raised by this Islamic figural emission, if the figure depicted on the obverse represented the Caliph 'Abd al-Malik, or the Prophet Muhammad, or was it to be understood as a depiction of the 'God of Muhammad', wrongly thought by some East Romans to be an idol of the Almighty worshiped by the Muslims, these were indeed questions of some serious consequence, and it was these specific questions which were raised concerning this specific image, together with the threat to insult the Messenger who had brought Islam, to publicly defame the Prophet Muhammad by means of 'an imprecation of the prophet' to be struck on the face of the widely circulated East Roman coinage, not any concern by this Caliph about the wider issue of the Muslim use of figural images per se, which led to the design and the issuing of the reformed Islamic coinage of 77 A.H./696-7 A.D. Figural works continued to be produced, including for example a statue of a Caliph, most probably depicting the Caliph Hisham 105-125/724-43 from Khirbat al-Mafjar that perhaps unsurprisingly carries some resemblances to the figure of the Caliph 'Abd al-Malik struck on this coinage (Fig. 10), although the sword hilt is grasped in the left, rather than the right hand.

Further, it maybe that this depiction of the "standing caliph" type with the prominent depiction of the sword in its scabbard, which has been described for example by Bernard Lewis as the, 'Sword of Islam', and, "this coin is thought to be the first showing the Sword of Islam.” (Lewis, 1992, 31, drawing an implicit connection with the Sura AtTawba 9:5, the 'Sword Verse', and the hadith, "All good lies under the sword and under the shadow of the sword."), and which is likewise remarked upon by Peter Sarris in 2013: "On the new coinage, either 
Muhammad or Abd al-Malik was depicted leading the faithful sword in hand" (Sarris, 2013, 299, although the sword is in fact represented sheathed and hanging, rather than naked and brandished, while any representation of, "the faithful" being led, is also entirely absent, except in some imaginations.), on these dīnār emissions struck between A.H. 74 and 77/693-4 and 6967 A.D., could be associated with the later belief held by many Christians for the "conversion through the sword" of Christian and other populations to Islam (The conversion of Pagan Makkans to Islam under the threat of death, such as in respect to the Murrite and Usamah, is recorded, Lings, 1983, 274-5. See also, Sura Al-Baqarah, 2: 191-4, in respect to idolatry being worse than carnage.), as earlier by Jews (For this implication before the issuance of this coinage see, Kaegi, 1997, 109, in respect to the text, Doctrina Iacobi nuper baptizati, of c. 634, and possibly informed by the judgement of Sa'd ibn Mu'adh in respect to the Bani Qurayzah and of the fall of Khaybar, and of Fredigarius in the late 650's, who attributed the victory at Yarmuk to "the sword of God", Kaegi, 1997, 213 and fn. 26), that is, for the compulsory conversion of Christians to Islam under the threat of death, somewhat different from Patriarch Sophronius' fear of barbarian invasion and of the bloody Saracen sword (Kaegi, 1997, 109), as being the real reason for the rapid spread of Islamic rule in the $7^{\text {th }}$ c. in formerly East Roman and largely Christian inhabited territory, but this is presently unclear and, although untrue, as the process of the conversion of the majority of inhabitants to Islam was neither quick, nor was it due to the threat of death from Muslim swords, nor was it particularly desired by the Muslim Arab conquerors (On the speed of conversion of native populations to Islam, see for example: Shaban, 1979; Hitti, 1991, 231-3; Bulliet, 1994, 8-9, 38, and 40, "Down to the end of the Umayyad period in 750...fewer than ten per cent of the non-Arab populace had converted" to Islam, and fig 3.1 indicating the rate of conversion.), it was a process that usually took about two centuries from conquest for the majority population to become Muslims (Different for example in the case of Anatolia where this process from 1071 onwards was broken in 1242 by the Pagan Mongol conquest, where in consequence the process lasted over a considerably longer period.), it is not perhaps impossible that some second hand knowledge of this image with its prominent sword struck on the coinage between A.H. 72 and 77 A.H. may have played some small part in fostering and supporting this later Christian myth of the 'conversion (to Islam) through the sword,' to account for the, to them, otherwise entirely inexplicably rapid spread of Islamic rule over vast areas of formerly Christian territory including Syria-Palestine, Egypt and North Africa, as a result of which by 77 A.H. 696-7 A.D. the majority of Christians had come under Muslim rule. 


\section{REFERENCES}

Akbari, S. C. (2012). Idols in the East: European Representations of Islam and the Orient, 1100-1450. New York: Cornell University Press.

Ainalov, D. V. (1961). The Hellenistic origins of Byzantine Art. Trans. S. Sobolevitch, Ed. C. Mango. New Brunswick, New Jersey: Rutgers University Press.

Arnold, T. W. (1965). Painting in Islam: A Study of the Place of Pictorial Art in Muslim Culture. New York: Dover.

Artuk, I. (1960). “Abbasiler Devrinde Sikke”. Belleten, 93, XXIV, 26-44.

Aydin, H. (2004). The Pavilion of the Sacred Relics The Sacred Trusts. New Jersey: The Light, Inc.

Barber, C. (2002). Figure And Likeness. Princeton and Oxford: Princeton University Press.

Barry, M. (2004). Figurative Art in Medieval Islam and the Riddle of Bihzad of Herat (1465-1535). Paris: Flammarion.

Batur, E. (1994). “A Rainbow Linking East and West-Coins of the Seljuks”. YKB Exh. Cat., No. 3, İstanbul: YKB.

Black, A. (2001). The History of Islamic Political Thought. New York: Routledge.

Blair, S. S. (1998). Islamic Inscriptions. New York and Edinburgh, New York University Press.

Bosworth C. E. (2004). The New Islamic Dynasties, Edinburgh: Edinburgh University Press.

Brend, B. (1991). Islamic Art. London: British Museum.

Brooks, E. W. (1899). “The Campaign of 716-18 from Arabic sources”. JHS, 19, 19-31.

Broome, M. (1985). A Handbook of Islamic Coins. London: Seaby.

Browne, E. G. (1997). A Literary History of Persia. Vol. I. Bethesda, MD: Ibex.

Bulliet, R. (1994) Islam The view from the edge. New York: Columbia University Press.

Burton, Sir R. F. (1964). Pilgrimage to Al-Madinah and Meccah. Vols. I, II. New York: Dover.

Colish, M. L. (1997). The Medieval Foundations of the Western Intellectual Tradition. New Haven \& London: Yale University Press.

Creswell, K. A. C. (1958). A Short Account of Early Muslim Architecture. London: Penguin.

Daftar, N. A. R. (1977). "The medallion of Caliph al-Mutawakkil". Numismatic Chronicle, CXXXVII, 170-1.

Daftar, N. A. R. (1980). “The medallion of Jafar al-Barmaki”. Numismatic Chronicle, 20, $7^{\text {th }}$ series.

Doughty, C. M. (1990). Travels in Arabia Deserta. Vol. I, Delhi: Manas.

Duggan, T. M. P. (2012). “On the tradition of Islamic figural sculpture to 1300”. Mediterranean Journal of Humanities, 2/1, 61-86.

Duggan, T. M. P. (2009). "Diplomatic shock and awe: moving, sometimes speaking Islamic statues". AlMasaq, Islam and the Medieval Mediterranean, 21/3, 229-267, December.

Ettinghausen, R., \& Graber, O. (1994). The Art and Architecture of Islam 650-1250. New Haven \& London: Yale University Press.

Falk, T. (1985). Treasures of Islam. Exh. Cat., Geneva: Phillip Wilson Pub.

Fairchild-Ruggles, D. Ed. (2011) Islamic Art \& Visual Culture An Anthology of Sources. Chichester: Wiley-Blackwell.

Fletcher, R. (1989). The Quest For El Cid. London: Hutchinson.

Goldziher, I. (1971). Muslim Studies II. Trans. C. R. Barber \& S. M. Stern, London: George Allen \& Unwin.

Graber, O. (1987). The Formation of Islamic Art. New Haven \& London: Yale University Press.

Graber, O. (1964). “Islamic Art and Byzantium”. D.O.P./18, 67-88

Hallaq, W. B. (2009). Sharia Theory-Practice-Transformations. Cambridge: Cambridge University Press.

Hanson, C. L. (2000). "Manuel I Comnenus and the "God of Muhammad": A study in Byzantine Ecclesiastical Politics”. Medieval Christian Perceptions of Islam, 55-82. Ed. J. V. Tolan. New York and London: Routledge. 
Hattstein, M., \& Delius, P. Eds. (2000). Islam-Art and Architecture. Cologne: Könemann.

Heidemann, S. (2010). "The Standing Caliph Type - the object on the reverse". Ed. A. Oddy. Coinage and History in the Seventh Century Near East/2, 23-34. Proceedings of the $12^{\text {th }}$ Seventh Century Syrian Numismatic Round Table held at Gonville, Caius College, Cambridge on $4^{\text {th }}$ and $5^{\text {th }}$ April, 2009.

Hitti, P. K. (1991). History of the Arabs. London: Macmillan.

Johns, J. (2003). “Archaeology and the History of Early Islam”. JESHO, 46/4, 411-436.

Kaegi, W. E. (1997). Byzantium and the early Islamic conquests. Cambridge: Cambridge University Press.

Karaman, H. Cağici, M. Dönmez, I. K., \& Gümüş, S. (2008) Ku'ran Yolu Türçe Meal ve Tefsir, V. Ankara: Diyanet Işleri Başkanlığı Yayınları.

Kennedy, H. (2008). The Great Arab Conquests. London: Phoenix.

Khaldun, Ibn (2005). The Muqaddimah-An Introduction to History. Trans. F. Rosenthal, Princeton and Oxford: Princeton University Press.

King, G. R. D. (1985). "Islam-Iconoclasm and the Declaration of Doctrine”. SOAS Bulletin, 48/2, 267-77.

le Strange, G. (1905). Lands of the Eastern Caliphate. Cambridge: Cambridge University Press

Lewis, B. (1992). "The Faith and the Faithful". The World of Islam, Faith, People, Culture, 25-56. London: Thames and Hudson.

Lings, M. (1983). Muhammad his life based on the earliest sources. New York: Inner Traditions.

Miles, G. C. (1967). “The Earliest Arab Gold Coinage”. ANSMN 13, 205-29.

Miles, G. C. (1952) "Mihrab and 'Anazah: A study in early Islamic Iconography". Archaeologica Orientalia in Memoriam Ernst Herzfeld, 156-171. New York: Locust Valley.

Nawawi, Imam Abu, Z. Y. (1989). Gardens of the Righteous: Riyadh as-Salihin. Trans. M. Z. Khan, London: Curzon Press.

Nawawi, Imam Abu, Z., (1993). Riyad us-Saliheen, The Paradise of the Pious. II, Trans. M. Matraji, F. A. Matraji. Beirut: Dar El-Fiker.

Ostrogorsky, G. (1969). History of the Byzantine State. New Brunswick-New Jersey: Rutgers University Press.

Öz, T. (1953). Hırka-i Saadet Dairesi ve Emanat-ı Mukaddese. İstanbul: Topkapı Sarayı Müzesi.

Pancaroğlu, O. (2005). “The Seljuks of Iran and their Successors”. Ed. D. J. Roxburgh. Turks: a journey of a thousand years 600-1600, 70-100. Exh. Cat. London: Royal Academy of Arts.

Peters, F. E. (1994). The Hajj, The Muslim Pilgrimage to Mecca and the Holy Places. Princeton, New Jersey: Princeton University Press.

Sarris, P. (2011). Empires of Faith The Fall of Rome to the Rise of Islam 500-700. Oxford: Oxford University Press

Serjeant, R. B. (1972). Islamic Textiles: Material for a History up to the Mongol Conquest. Beirut: Libraire du Liban.

Senturk, S., \& Özpalabiyiklar, S. Eds. (2004) Power of Gold, Golds of Power. İstanbul: YKY

Shaban, M. (1979). “Conversion to Early Islam.” Ed. N. Levizion. Conversion to Islam, 24-29. New York-London: Holmes \& Meier.

Theophilus of Edessa's Chronicle and the Circulation of Historical Knowledge in Late Antiquity and Early Islam. R. G. Hoyland, Trans. Ed. \& Notes. Liverpool University Press, 2011

Treadwell, L. (2009). “Abd al-Malik's coinage reforms: The role of the Damascus Mint”. Revue Numismatique, 6, 165, 357-381.

Treadwell, L. (2005). 'Mihrab and 'Anaza'or 'Sacrum and Spear'? A Reconsideration of an Early Marwanid Silver Drachm.' 1-28 in, Muqarnas 30.

Uzunçarş11, I. H. (1959). Topkapi Sarayi Muzesi Mühürler Seksiyoni Rehberi.

Vasiliev, A. A. (1954). "The iconoclastic edict of the Caliph Yazid II.” D.O.P. 8.

Whittow, W. (1996). The Building of Byzantium 600-1025. Oakland: University of California Press.

Wolf, K. B. (2000). “Christian Views of Islam in Early Medieval Spain”. Ed. J. V. Tolan. Medieval Perceptions of Islam, 85-108. New York and London: Routledge. 